IRSH 52 (2007), pp. I33-I5I DOI: I0.1017/S0020859007003 I6I

(C) 2007 Internationaal Instituut voor Sociale Geschiedenis

\title{
Antagonism, Absurdity, and the Avant-Garde: Dismantling Soviet Oppression through the Use of Theatrical Devices by Poland's “Orange” Solidarity Movement*
}

\author{
L IS I UNIA A. ROMANIENKO
}

SUMmARY: Since the birth of Solidarity twenty-five years ago, scholars have examined this unique Polish apparatus of defiance from nearly every institutional perspective known to the social sciences. Yet very little attention has been paid to the role of the human agency that gave rise to this powerful force of national resistance. Even less attention has been devoted to the influence of emotion, and of laughter in particular, in mobilizing this unprecedented scale of subversive activities against the Soviet empire. By deploying discursive devices offered through avantgarde performance, Solidarity's regional art student faction known as the "Orange Alternative" helped to dismantle Soviet aggression by unifying Poles under the rubric of culturally specific nostalgic humour. Low state capacity, recognition claims for optimizing human potential, and other microdynamics of oppositional consciousness are some of the factors discussed which enabled humour to strengthen the movement and prevent exogenous special interests from altering its objectives.

\section{INTRODUCTION}

Prior research has documented the history of Poland's Solidarity movement from a variety of systemic perspectives. These approaches tend to limit their focus on Polish transformation in the light of exogenous influences, as either a vehicle for organizing proletarian labour, ${ }^{\mathrm{I}}$ as a tool

\footnotetext{
* This research was made possible by a grant from the Kosciuszko Foundation. An earlier version was presented at the 2007 Alternative Futures and Popular Protest Conference in Manchester. The author would like to thank Waldemar Major Fydrych, Ludwika Ogorzelec, Colin Barker, and several anonymous reviewers for their assistance in the preparation of this manuscript. Please address all inquiries to lroman@ix.netcom.com.

I. Alain Touraine et al., Solidarity: The Analysis of a Social Movement: Poland, 1980-198I (New York, 1983).
} 
for Western global hegemonic interests against the Soviet Union, ${ }^{2}$ or as an instrument for liberation theology due to its ties with the Vatican. ${ }^{3}$

While such macrostructural arguments clearly present valid portrayals of some of the economic, political, and ideological factors that contributed to the success of Solidarity and the simultaneous demise of the Soviet Union, they do not comprehensively address the crucial role of spontaneous unscripted human agency in successfully defeating the Soviet totalitarian regime. By focusing exclusively on the role of exogenous institutional variables such as intergovernmental organizations like the World Bank and the International Monetary Fund, the schism between Roman Catholic and Russian Orthodox churches, the Kremlin's thawed policies of perestroika, or the North Atlantic Treaty Organization, transitology scholars have failed to capture with any level of specificity the unique endogenous resistance tactics exhibited by Solidarity movement members in street-level demonstrations.

Despite scholarly portrayals to the contrary, strategies used by Solidarity did not merely involve rational, premeditated, judicious decision-making by astute striking shipyard workers that promoted what social scientists since the I970s have called a "self-limiting revolution". Solidarity's success was to some extent contingent upon the spontaneous theatrical device of bumour, which has somehow been completely overlooked in twenty-five years of retrospective transformation analyses. ${ }^{4}$ It was the dramaturgical interactions inspired by the avant-garde theatrical performance genre known as the Theatre of the Absurd that significantly contributed to the dismantling of Soviet repression, while preventing the bloodshed that was so prevalent in the earlier coups crushed by the apparatus since its inception.

Is it conceptually feasible to assert the primacy of human emotion, or more specifically humour, in demystifying the tense interactions between powerless, unarmed Solidarity members and excessively militarized communist authorities? Can absurdity and related humorous theatrical devices meet the paradigmatic criteria for a successful social movement? Does humour really have such aggression-dismantling capabilities and if

2. Elizabeth Teague, Solidarity and the Soviet Worker: The Impact of the Polish Events of 1980 on Soviet Internal Politics (New York, I988).

3. John J. Bukowczyk (ed.), Polish Americans and their History: Community, Culture, and Politics (Pittsburgh, PA, 1996).

4. See for example Luis Landau, Poland Country Assistance Review: Partnership in a Transition Economy (Washington DC, 1997); Gerald L. Miller and Wilburn T. Stancil (eds), Catholicism at the Millennium: The Church of Tradition in Transition (Kansas City, KS, $200 \mathrm{I}$ ); William Elliot Butler (ed.), Perestroika and the Rule of Law: Anglo-American and Soviet Perspectives (New York, I99I); S. Nelson Drew, NATO from Berlin to Bosnia: Trans-Atlantic Security in Transition (Washington DC, 1995); Neal Ascherson, The Polish August: The Self-Limiting Revolution (Harmondsworth, 1982); Colin Barker, Festival of the Oppressed: Solidarity, Reform and Revolution in Poland (London, 1986). 
so, what features does this contestation process possess? If humour's efficacy can indeed be genuinely established, why have scholars previously failed to document the phenomenon with any depth or substance? In the spirit of the challenge I have set forth, this article will provide a relevant theoretical perspective to frame the Solidarity movement emotionally, illustrate the artistic historical antecedents that influenced the strategic integration of humour among regional movement members, describe the political events leading to the formalization of these theatrical devices within resistance frameworks, explore humour as a mobilizing strategy to address and contest societal inequalities, and discuss the feasibility of theatrical absurdity and related comedic tools to serve as oppositional mechanisms in contemporary socioeconomic and political struggles for the future.

\section{MEDIATING STRUCTURES}

Power arrangements between state and non-state actors have been an important area of historical analysis of social movements. Relationships between these actors have been defined in a variety of ways, such as mediating structures to buffer the effects of market forces, as reflecting collusive corporatism, as coercively aligned with for-profit interests, as cooperatively aligned with non-profit organizations to fulfil welfare obligations, as indicative of the rise of normative state functions, and as evidence of overall declining state capacity. 5 The study of relationships between state and non-state actors from these diverse approaches underscores the notion of reciprocity, where state power is not only taken by non-state forces which are often coercively oppositional, but where power to non-state actors is sometimes also voluntarily given by the state. ${ }^{6}$ These negotiated relations among state and non-state actors are not limited to advanced industrialized capitalist societies, but can be applied to a socialist context to demystify transitional power-sharing with the communists. Tilly refers to the process as brokerage among political entrepreneurs and violence specialists. ${ }^{7}$ As noted by Cowles, power-sharing "takes place

5. See for example Peter L. Berger and Richard J. Neuhaus, To Empower People: From State to Civil Society (Washington DC, 1996); Phillippe C. Schmitter, "Dangers and Dilemmas of Democracy", Journal of Democracy, 5:2 (1994), pp. 57-74; Timo Airaksinen, Ethics of Coercion and Authority: A Philosophical Study of Social Life (Pittsburgh, PA, I988); John Clarke, Allan Cochrane, and Carol Smart, Ideologies of Welfare: From Dreams to Disillusion (London, 1987); Helene Sjursen, “The EU as a 'Normative' Power: How Can This Be?”, Journal of European Policy, I3 (2006), pp. 235-25I; Maria Cowles, "Non-State Actors and False Dichotomies: Reviewing IR/IPE Approaches to European Integration”, Journal of European Public Policy, io (2003), pp. 102-I 20.

6. John C. Leggett, Taking State Power: The Sources and Consequences of Political Challenge (New York, 1973).

7. Charles Tilly, The Politics of Collective Violence (Cambridge, 2003). 
precisely because states and public institutions do not have the proper mechanism to cope with [complex situations]". 8

I assert that communist officials did indeed have low or no state capacity in dealing with the complex socioeconomic and cultural problems that led to the Solidarity uprisings, and this declining state capacity was further paralysed through the theatrical device of street-level demonstrations involving humour. Furthermore, because of the intensity of the absurdity of humorous devices employed in resistance messages, the Soviet apparatus was unable to fragment Polish opposition through the standard coercive tactics typically used by the regime. Spontaneous collective comprehension of humorous nuances unified Poles on both sides of the ideological battle, thus preventing exogenous state actors in Moscow from mandating violence to quell uprisings. The reluctance of Poles to consider the possibility of resorting to violence in an atmosphere of humorous absurdity paradoxically legitimized both state and non-state actors alike, and ultimately enabled temporary power-sharing through non-coercive, voluntary authority transfers from communist authorities to high-ranking Solidarity members. ${ }^{9}$

According to Bergson,

However spontaneous it seems, laughter always implies a kind of secret [...] complicity with other laughers, real or imaginary. [How] often has the remark been made that many comic effects are incapable of translation from one language to another, because they refer to the customs and ideas of a particular social group! [...] To understand laughter, we must put it back into its natural environment, which is society, and above all must we determine the utility of its function, which is a social one. [Comedy] expresses an individual or collective imperfection which calls for an immediate corrective. That corrective is laughter, a social gesture that $[\ldots]$ implies a secret or unconscious intent [to correct] all events in society as a whole. ${ }^{10}$

Biological and social scientists have suggested that laughter functions to demonstrate trust, to cope with infirmity and vulnerability, to mask fomenting hostility, to exhibit cultural competence, to convey the absence of threat and group wellbeing, to temporarily subvert social inequalities, as a socialization and acculturation tool, and as a condescending device to challenge rank. ${ }^{\text {II }}$ Humour is therefore a highly complex mechanism that

\footnotetext{
8. Cowles, "Non-State Actors and False Dichotomies", p. ı०8.

9. Collin Barker, "Fear, Laughter, and Collective Power: The Making of Solidarity at the Lenin Shipyard in Gdansk, Poland, August 1980", in Jeff Goodwin, James M. Jasper, and Francesca Polletta (eds), Passionate Politics: Emotions and Social Movements (Chicago, IL, 2001), pp. I75I94.

I0. Henri Bergson, "Laughter", in Robert W. Corrigan (ed.), Comedy: Meaning and Form (San Francisco, CA, 1965), p. 473 .

I I. See for example Kate Douglas, "What Are You Laughing At?", New Scientist, i 80 (2003), pp. 2426-2428; Alicja Rieger, "Explorations of the Functions of Humor and Other Types of Fun
} 
universally functions to delineate group membership, as well as ubiquitously to signify collective agreement that the limits of convention have somehow been violated. Before examining this intricate process in greater detail, it may be useful to explore the conditions enabling Solidarity to accomplish its objectives efficiently by evolving into an opportunistic social movement apparatus utilizing humorous paradigmatic devices associated with the avant-garde Theatre of the Absurd.

\section{RESISTING FRAGMENTATION}

While of considerable interest to social scientists, the macrostructural conditions of the socioeconomic and political environment in which the Solidarity movement was embedded have little direct influence on the willingness of women and men regularly to participate in street-level demonstrations, particularly in light of the threat of inhumane incarceration in remote places like Siberia, infamous Soviet resocialization programmes, arbitrary disappearances, murders, and other dictatorial intimidation tactics that posed risks to citizens' safety and that of their families.

Proponents of the "self-limiting revolution" school of literature are quick to point out that the Solidarity movement was initially one involving labour, whose primary intention was not to promote ideological transformation from socialism to capitalism, but rather to enhance concretely the economic quality of life under the existing system of Soviet-style socialism. ${ }^{2}$ These analyses have sufficiently demonstrated that wages and working conditions were indeed the primary driving forces behind the original national movement, composed not only of male and female shipyard workers but of exiled dissidents, students, artists, priests, nuns, and ironically, members of the obligatory-service national militia. Solidarity was so inclusive a social movement that even elderly greatgrandmothers had specific sombre functions involving spontaneous unscripted resistance, through performative melodramatic weeping and solemn public collective prayer. According to Piven and Cloward, it is important to examine

among Families of Children with Disabilities", Research and Practice for Persons with Severe Disabilities, 29:3 (2004), pp. 194-209; Arthur Asa Berger and Aaron Wildavsky, "Who Laughs at What?", Society, 3 1:6 (I 994), pp. 82-86; Jack Katz, "Families and Funny Mirrors: A Study of the Social Construction and Personal Embodiment of Humor", American Journal of Sociology, ro I (1996), pp. I I 94-I 237; James Butcher, "Have you Heard the One about the Prefrontal Cortex?", The Lancet, 358 (9299) (2001), p. 2136; Hans Speier, "Wit and Politics: An Essay on Laughter and Power", American Journal of Sociology, I03 (1998), pp. I352-1401; Robert A. Stebbins, "The Role of Humour in Teaching: Strategies and Self-Expression", in Peter Woods (ed.), The Role of Humour in Teaching: Strategies and the School (London, 1980); Sarah Tragesser and Louis Lippman, "Teasing: For Superiority or Solidarity?”, The Journal of General Psychology, I 32 (2005), pp. $255-266$.

I 2. Jadwiga Staniszkis, Poland's Self-Limiting Revolution (Princeton, NJ, 1984). 
[...] social locations and forms of defiance. [People] experience deprivation and oppression within a concrete setting, not as the end product of large and abstract processes, and it is the concrete experience that molds their discontent into specific grievances against specific targets. Workers experience the factory [...] they do not experience monopoly capitalism. ${ }^{\mathrm{I}}$

Thus, the underlying features of street-level interactions, or what Della Porta calls the "microdynamics of participation", should be of substantial interest to social scientists. ${ }^{14}$

One crippling modus operandi of dictatorial communism was alienation through emotional social distances, captured perhaps most dramatically in Czeslaw Milosz's body of work. ${ }^{15}$ The socialist state, through a variety of divisive authoritarian mechanisms, attempts to fragment society by weakening social ties in all spheres of public and private life. Paralysing passivity is encouraged and rewarded, while the individual is acculturated to rely on the monolithic state to make any permissible social contacts possible. ${ }^{16}$ In that way, relations between intimate partners, family members, friends, citizens with similar recreational interests, and any other community contacts are highly regulated and mediated through centralized communist authorities.

Nowhere was the Soviet tactic of community repression more of an abysmal failure than in Poland. Communist efforts to fracture Polish society would only lead to persistent resistance through defiant unification and heightened social solidarity, hence the movement name. Centuries of historical oppression by neighbouring hegemonic interests, Io० years of partitioning out of existence, criminalization of the language, forced migrations, an anomalous absence of ethnic and religious minorities, and the inability of Poles to accept Soviet-designed normality were some of the conditions that together prevented state-engineered, paranoia-based terror from dividing Polish society.

\section{SOLIDARITY AS RECOGNITION MOVEMENT}

In contrast to the reductivist portrayals that focused on shipyard resistance efforts and gravely oversimplified an otherwise highly complex and diverse apparatus of national dissent, Solidarity was, in fact, much broader

I3. Frances Fox Piven and Richard A. Cloward, Poor People's Movements: Why They Succeed, How They Fail (New York, 1979), p. I9.

I4. Donatella Della Porta, "Comparative Politics and Social Movements", in Bert Klandermans and Suzanne Staggenborg (eds), Methods of Social Movement Research (Minneapolis, MN, 2002), p. 302.

15. Czeslaw Milosz, The Captive Mind (New York, I990).

I6. The art historian Juliusz Tyszka refers to these as "tectonic social processes". See Juliusz Tyszka, "The School of Being Together: Festivals as National Therapy during the Polish 'Period of Transition'”, New Theatre Quarterly, I3:50 (1997), pp. I71-I 82. 
than merely an intelligentsia-backed industrial labour movement on the Baltic Sea. Within Solidarity, many factional identity-construction processes and recognition struggles were simultaneously taking place. Solidarity provided an innovative platform of departure and a dramaturgical stage of performance for many diverse suppressed groups in Polish society. While momentum for the Solidarity social movement intensified, and as the floodgates for public discourse began to open, these marginalized voices gradually interjected their eclectic vision into the national dialogue of defiance. Over time, the movement became a longitudinal mechanism of discursive dissent, moving Solidarity from a skeletal antagonistic claimant movement focusing on redistribution of resources, to a fully matured, acculturated urbane recognition movement, enabling the most salient cultural identities to ascend to leadership functions; in this way the method, mechanism, and objectives of the Polish struggle were articulated and influenced to mesmerized international audiences around the globe.

Antagonistic claimant movements are defined as an "organized system seeking distribution of rewards [intentionally] challenging the existing status quo". ${ }^{17}$ Recognition movements, on the other hand, are more complex, involving struggle for public acknowledgement involving " $\mathrm{a}$ form of claims-making linked to [resistance] outcomes". ${ }^{18}$ Recognition struggles are not, incidentally, limited to participants in social movement organizations, but have been advanced as a form of human agency crucial for the full development of our human potential. According to Honneth, "the moral quality of social relations cannot be measured solely in terms of the fair or just distribution of material goods; rather, our notion of justice is also closely linked to how, and as what, subjects mutually recognize each other". ${ }^{19}$ This led to the development of three philosophical dimensions of recognition advanced by Hegel as necessary for optimizing human potential: found in the driving needs of intimate relations, in the family unit, and in citizens' relationship with the state. ${ }^{20}$ The human being is therefore free to fulfil his or her potential only when intimates, family members, and the state acknowledge and recognize him or her as possessing certain possibilities for action. The individual, in turn, must facilitate reciprocity in granting intimates, family members, and the state the same morally legitimizing recognition.

There are some rare exceptions noted. Parents and their children, for

17. Graeme Chesters and Ian Welsh, Complexity and Social Movements: Multitudes at the Edge of Chaos (London, 2006), p. 98.

I8. Barbara Hobson, "Introduction", in Barbara Hobson (ed.), Recognition Struggles and Social Movements: Contested Identities, Agency and Power (Cambridge, 2003), p. I.

19. Axel Honneth, "Recognition and Moral Obligation", Social Research, 64 (1997), pp. I6-35, I7.

20. Georg Wilhelm Friedrich Hegel, Philosophy of Right (Oxford, 1957). 
example, represent non-reciprocal, asymmetrical relations due to requisite caretaking functions. But in other circumstances, reciprocal recognition claims are publicly and privately established through a variety of actionoptimizing mechanisms, so that successful social movement organizations seeking to optimize the potential of an oppressed group can provide an important impetus for peripheralized recognition claims to be shifted and centralized. According to Hiller, "social movements are, by definition, conscious attempts to bring about or resist change [so] they inevitably create conflict. Some forms of conflict are the result of a planned and sponsored strategy, but others [...] emerge spontaneously among the followers or at the margins of organized movements." ${ }^{21}$ In this way, divergence typically arises within a given social movement as a result of heterogeneous and competitive impetus for recognition claims. In examining artistic discursive devices distinguishing "Orange" Solidarity resistance tactics, unique contestational movement microdynamics can be thoroughly elaborated.

\section{ABSURDITY AND THE ORANGE ALTERNATIVE}

By integrating these paradigmatic frameworks, our analysis can now arrive at certain postulates. The current treatment suggests that recognition claims made by social movement organizations have significant potential for success when operating under three microdynamic conditions. The first condition that enhances the likelihood of success is the presence of an anxious, stake-holding audience. The second is low or no state capacity with the prevalence of asymmetrical relations between state and non-state actors, where the state holds power and authority to grant or fulfil recognition claims and where human potential is consistently thwarted. Third, in situations where the state reflects low or no capacity, but still refuses to grant recognition claims to non-state entities for identified or unidentified reasons, the struggle for members to optimize their human potential will compel social movements to develop innovative resistance repertoires by deploying appreciably creative, often competitive mechanisms that are negatively correlated with state capacity.

In other words, the lower the state's capacity, the higher the level of creativity, innovation, and competitiveness that social movement organization's resistance tactics will exhibit. The higher the state's capacity, the lower the level of creativity, innovation, and competitiveness that resistance tactics will possess. Thus, the extent to which social movements allow competing factions within resistance repertoires to use creative devices in order to persuade state actors to acknowledge recognition claims 
is directly correlated with state capacity for suppression of dissent, especially through a state monopoly on violence. As noted by Williams,

Looking more deeply into spirit, at its center Hegel believes is a rational freedom, which demands and struggles for recognition. The demand for recognition of freedom leads to criticism of coercion; coercion is inherently self-contradictory and self-subverting. It leads to social and political criticism of inequalities, including mastery and slavery, and on higher levels [...] authoritarian positivity and tradition. ${ }^{22}$

The most influential Solidarity faction that demanded and obtained central recognition whose unique critique of coercion through pacifist mechanisms of discursive dissent enabled Solidarity to ultimately prevail was the Orange Alternative, situated in the bohemian community of Wrocław. Founded in the south-west corner of Poland, this historically relevant region was annexed to Poland after World War II and, as a result, became a diasporic assemblage of Polish citizens who were forced from Polish lands annexed to the Ukraine, Lithuania, and Belarus. With the new postwar redistricting haphazardly designed at Yalta under the authority of Roosevelt, Churchill, and Stalin, coupled with the expulsion of German citizens to provinces further west, Wrocław was able to evolve into an alternative artistic enclave and a haven for Polish exiles from around the world. ${ }^{23}$ Under geopolitical conditions resembling tattered patchwork, religious pluralism was transmitted with this reluctant migration of Polish war survivors, as the region became infused with Orthodox Christianity from its pre-war eastern borders whose allegiance to the Vatican was tenuous at best. As a result of these distinct political, social, and cultural factors, eclectic alternative artistic and cultural communities flourished there after reconstruction. The arts were infused with international bohemian elements injecting refreshing theoretical, philosophical, and surreal paradigmatic frameworks drawn from cultural influences around the globe.

One of these was the avant-garde performance art genre, the Theatre of the Absurd, which rooted itself in Wrocław's alternative theatrical and cultural underground community in exile, and later more formally through institutional arrangements within Wrocław University. ${ }^{24}$ Scholars could not possibly predict that four decades later, these circumstances would inadvertently change the course of Soviet efforts at regional

22. Robert R. Williams, Hegel's Ethics of Recognition (Berkeley, CA, I997), p. 24.

23. Tyszka calls Wrocław "the most powerful center of resistance against Communist power" and attributes this to avant-garde theatre under the tutelage of Jerzy Grotowski, Henryk Tomaszewski, Jerzy Grzegorzewski, Kazimierz Braun, and Tadeusz Różewicz; Juliusz Tyszka, "The Orange Alternative: Street Happenings as Social Performance in Poland under Martial Law", New Theatre Quarterly, I4:56 (1998).

24. Piotr Piotrowski, Awangarda w Cienu Jalty (Poznań, 2006). 
domination. The Absurd and other forms of socialist surrealism ${ }^{25}$ offered the postwar, utopian-building, dissident community in exile a vehicle for struggle and a mechanism for expressing the smouldering national discontent that would later manifest as Solidarity, one of the most influential social movements in the history of the modern world. Eloquently described by Martin Esslin,

In the early i950s [...] it appeared as though the Theatre of the Absurd introspective, oblivious of the social problems and their remedies - was the very antithesis of the political theatre as preached by [...] the official arbiters of the arts in the Soviet Union and her bloc. [By] exploring the perplexity of man confronted by a soulless, over-mechanized, over-organized world, [the Absurd] had not only forecast the essentials of developments such as concentration camps or the bureaucratic tyrannies of totalitarianism, but had in fact described their essence more accurately and more truthfully than any purely naturalistic novel could have done. When [the Absurd was] performed in Poland at the time of the thaw of 1956 , the audience there immediately understood it as a portrayal of the frustration of life in a society which habitually explains away the hardships of the present by emphasizing [Soviet delusions for the future]. And it soon became clear that a theatre of such concretized images of psychological dilemmas and frustrations which transmuted moods into myths was extremely well-suited to deal with the realities of life in Eastern Europe. ${ }^{26}$

As communist authorities expelled an overwhelming number of students from their studies at Wrocław University and the Wrocław School of Fine Arts due to their work in the Solidarity movement, it was one artist-activist in particular, Waldemar Major Fydrych, who founded Solidarity's Orange Alternative. ${ }^{27} \mathrm{He}$ was primarily responsible for infusing the Absurd into the national repertoire of defiance, this providing the Solidarity movement with a timely resistance device for humorous, peaceful retaliation against Soviet opposition. The antithesis of autocratic Lech Wałęsa, Major and his team of talented provocateurs had an acknowledged record of dramaturgical, non-violent, humanist, pacifist, feminist, anarchist, ecological, sexual, and human rights advocacy; as well as an ability to inclusively articulate, through accessible verbal and nonverbal discursive mechanisms, complex theatrical paradigms relevant to an attentive but defiant working-class audience. ${ }^{28}$

Under Major's anti-hierarchical, meta-subversive, anti-leadership lea-

25. Anna Husarska, "Socialist Surrealism in Poland", New Leader, 71:I3 (1988).

26. Martin Esslin, Theatre of the Absurd (New York, 2004), p. 3 I6.

27. John Tagliabue, "Police Draw the Curtain but the Farce Still Plays", New York Times, I4 June 1988.

28. See Michał Balcerzak’s film "Nocna Zmiana”, a documentary demonstrating Wałęsa’s dictatorial style of leadership: http://video.google.pl/videoplay?docid=2 I 850584 I 3755445485 (last accessed I 8 May 2007). See also Mirosław Dembeski's film, "Pomarańczowa Alternatywa", a documentary demonstrating the Major's anti-hierarchical leadership style: http://www. pomaranczowa-alternatywa.republika.pl/filmy.html (last accessed 28 May 2007). 
dership style, the Orange Alternative was thrust into the choreographic spotlight, designing unprecedented public theatrical resistance productions never before attempted on such a grand scale. ${ }^{29}$ These productions gradually coalesced into some of the most dramatic demonstrations of the entire Solidarity era. One might question how such an important faction of Solidarity should come to be centred upon a colour.

Major's Orange Solidarity faction was a symbolic critique, a visually radiant metaphor, inspired by Buddhism but designed to encourage a refreshing new movement direction that defined the imminent path that was needed for Solidarity's struggle against totalitarianism. As tensions heightened, daily life under martial law becoming increasingly unbearable, there were acute state shortages of material goods such as milk and sanitary protection needed for subsistence living, threats of incarceration and torture associated with an impending state backlash, and endless concessionless negotiations with communist officials that consistently failed to produce the intended results; the Orange Alternative concurrently engaged in abstract Absurd devices such as the public distribution of women's sanitary protection products. Through cooperative acts involving the distribution of this and other scarce commodities, Orange was able simultaneously to elucidate the insanity of their current circumstances of existence, the surrealistic failures of socialism's pledge of abundance, the potential for material acquisition through Orange's penetration into the underground, and the possibility of breaking through the stagnancy, stalemate, and scarcity that was characteristic of the time.

Solidarity embodied a collective empowerment for a utopian vision that was long fought for, but was becoming increasingly appropriated by two international special interests, located squarely in the polarization of church and state. Wrocław's expelled students conceptualized Orangevity as a new humanist orientation that thrust the otherwise wounded Solidarity movement into an Absurd but safe Orange space, representing a non-institutionalized middle ground between the abysmal hopelessness represented by the deep ideological divide between Christianity and socialism. Orange represented a mythical zone of safety and wellbeing, a fictitious world of childhood allegorical fantasy, located between the two equally dystopian options for Poland's future offered by the Vatican and the Soviets. Solidarity's path as seen through the lens of the Orange Alternative was to be outside and beyond the possibilities driven by two incapacitating visions of the future painted by church in Vatican yellow and state in Soviet red.

By conceptually juxtaposing these institutions in this metaphorically absurd apparatus of Orangevity, Major's factional movement was a 
critique of the exogenous special institutional interests that were complicating Poland's struggle for survival. The Orange Alternative served as a moral reminder for Solidarity's members not to allow themselves to be dismissed, deconstructed, or otherwise unintentionally exploited by powerful international agenda-setting players taking on the Kremlin, namely the triumvirate team of potent provocateurs composed of British Prime Minister Margaret Thatcher, United States President Ronald Reagan, and Polish Pope John Paul II. Orange was a reminder that in its earliest origins Solidarity had been, and was to remain, a grassroots social movement by the people for the people. This reality was, however, becoming inadvertently manipulated as the Polish intelligentsia, headed by an unseasoned pipefitting welder named Lech Wałęsa, became increasingly predisposed to these elite influences during tense negotiations. The Orange Alternative was an important patriotic, anarchistic, theatrical resistance faction, using protest and performance as a vehicle to articulate, through dramaturgical discursive frameworks, the importance of preventing the movement from being usurped or confounded by well-intentioned but highly manipulative interests interjecting their political agendas from outside Poland.

\section{DEVICES OF THE ABSURD}

To that end, Orange Alternative members chose to demonstrate their disingenuous obedience to both systems of patriarchal oppression situated in church and state by utilizing nostalgic devices inherent in childhood nursery rhymes. Orange Solidarity members arrived at scheduled and unscheduled spectacularized public protests called "Happenings" dressed in orange elf costumes to perform their infantile societal function as obedient children by dancing carelessly at these demonstrations throughout the city of Wrocław. They frolicked around Soviet tanks, they sang nursery rhymes through streets blocked by overturned trams, they danced around burning military vehicles, they skipped about twisted metal and burning rubber, they even held hands and sang songs in infantile fashion poised in front of menacing weapons positioned on heavy military vehicles engaged in crowd control to isolate protesters throughout the city..$^{30}$

The absurdity of the scenarios they created helped to dismantle aggression among all Polish participants including communist agents, but also among agitating Solidarity factions who were determined to shed blood to bring a swift end to the tortuous struggle. The childhood devices demonstrated by hundreds and later thousands of artists dressed as orange

30. Bronisław Misztal, "Between the State and Solidarity: One Movement, Two Interpretations - The Orange Alternative Movement in Poland”, British Journal of Sociology 43 (1992), pp. $55-78$. 


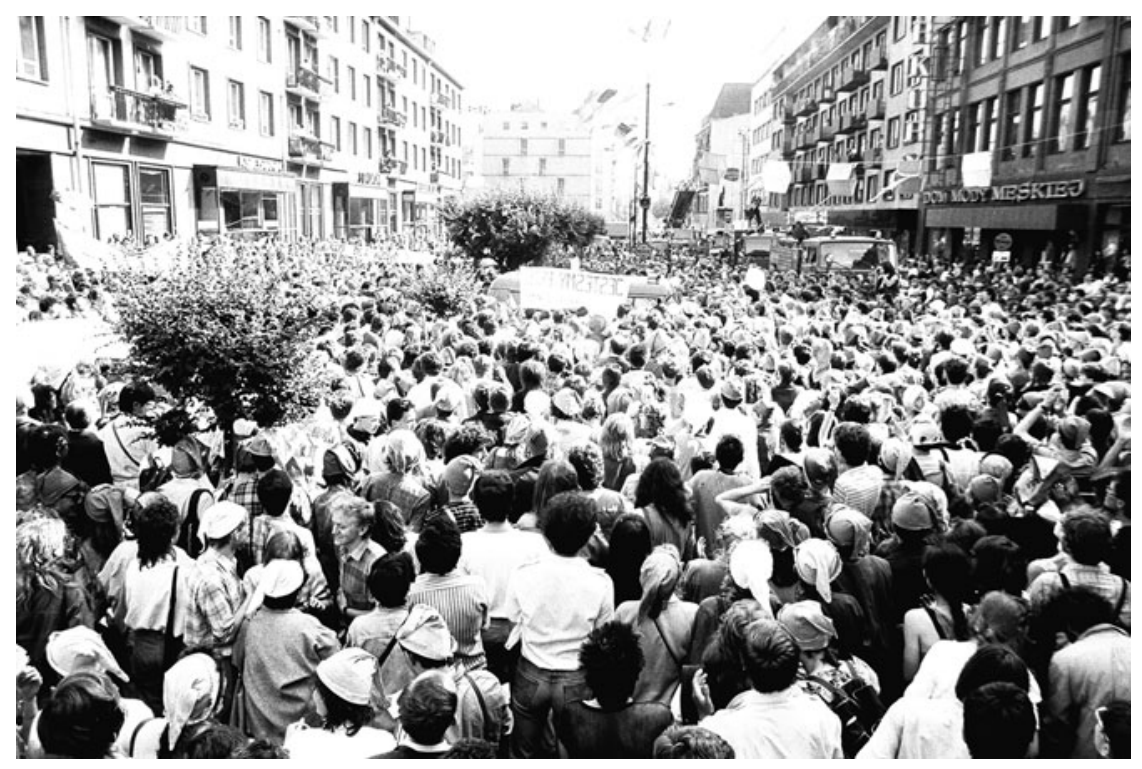

Figure I. Mass crowds dressed as elves in orange caps prepare for a "Happening" in Wroclaw. Waldemar "Major" Fydrych's personal archives

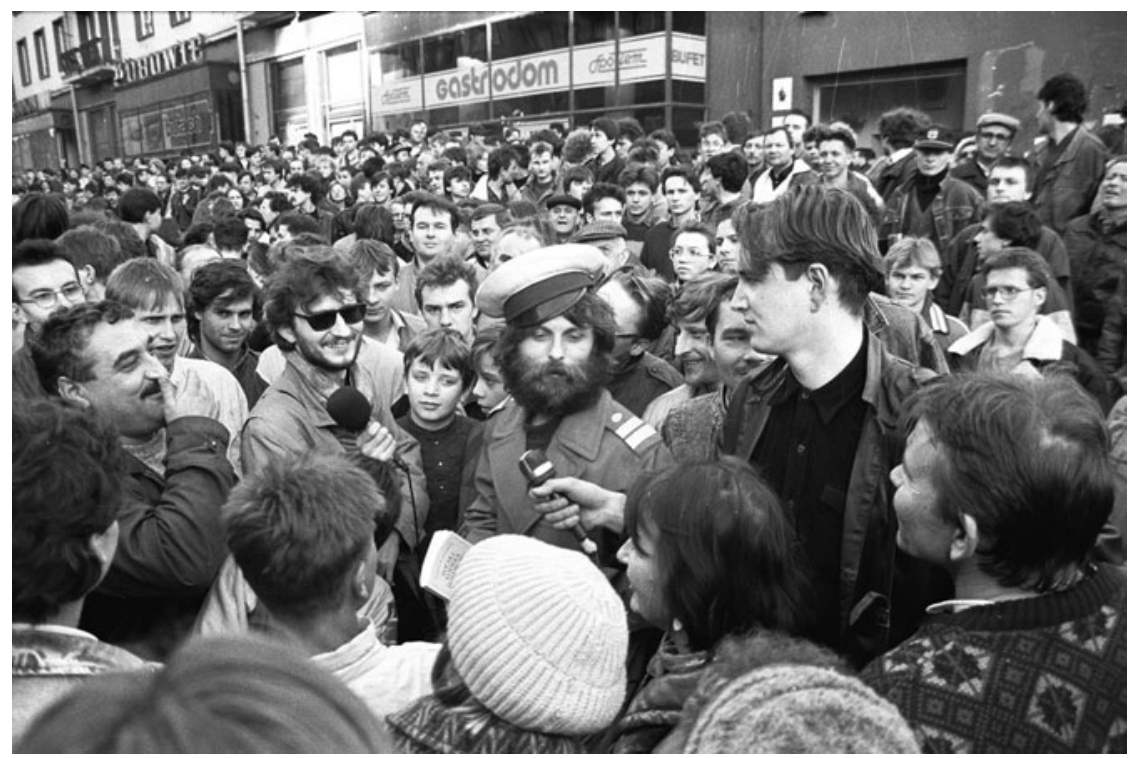

Figure 2. Major, founder of the Orange Alternative, discussing elves with the media. Waldemar "Major" Fydrych's personal archives 
elves (known in the Polish vernacular as Krasnoludki) universally triggered nostalgic memories of Polish nursery rhymes among both communists and Solidarity. These nostalgic devices involving mythical figures who discreetly and clandestinely accomplished all of society's necessary but complicated tasks elicited humorous emotions among demonstrators and the military. Soldiers could no longer raise their weapons against their comrades, tank operators could not hold their positions against their fellow citizens, and Solidarity members with a penchant for violence could no longer fantasize about retribution against the young confused soldiers in their midst. According to G.S. Amur,

Perhaps, one of the greatest services that [...] comedy has rendered humanity is its effective treatment of the ugly and the imperfect in human life. By providing a perspective and a point of view which enables us to contemplate the imperfection of human life without experiencing the pain that accompanies such a contemplation, [comedy] removes a serious obstacle to human happiness. [By] exposing and ridiculing human error, it promotes wisdom among men and acts as an agent of purification. The traditional concept of the ridiculous as some sort of human imperfection or defect has found favour with many modern thinkers. The ridiculous, if it is to be a source of pleasure, must not only be recognised but also overcome. In fact, the contemplation of the ridiculous is pleasurable only when we are strong enough to conquer it. [Yet] another important component of the spirit of comedy [is] its essentially good nature and kindliness. ${ }^{3 \mathrm{I}}$

The non-violent resistance tactics clarifying Solidarity's purpose exhibited through Major's Orange productions were not, however, limited to audiences participating in protests in Wrocław. As news of his imprisonment for "public agitation by impersonating an elf" spread throughout the Solidarity underground, similar Orange productions began taking place in Cracow, Warsaw, Gdańsk, and beyond. A petition signed by Polish artists with international acclaim, including Oscar-winning director Andrzej Wajda, demanded Major's immediate release from prison. The petition was effective, and his court proceeding for elf impersonation was attended by renowned members of Poland's artistic community. This stage set became yet another public opportunity for avant-garde Orange contestation of state encroachment into private life. In order to attend the trial, Major's supporters, men and women, all had to introduce themselves as his fiancée or fiancé. The elf impersonation charges were subsequently dismissed, resulting in Major's release into the custody of his betrothed collective.

As word of the bizarre tactics of resistance spread to the Kremlin through public testimony submitted by Poland's astounded apparatchik, General Wojciech Jaruzelski, state legitimacy hung precariously low as violence against such playful, youthful citizens could not be deployed

3I. G.S. Amur, The Concept of Comedy: A Re-statement (Folcroft, PA, 1977), p. 2 I. 
under the watchful gaze of international audiences from the West. The frivolous play of orange elves unintentionally placed the entire doctrine of Soviet-style socialism under global scrutiny. Many demonstrations were scripted in this way, involving a variety of Absurd theatrical devices that cannot be described given the limits of the current treatment, but whose tactics were nevertheless consistently innovative. Misztal has noted "[The Orange Alternative] dispelled the myth of political order, thus doing away with fear. [...] It runs contrary to the original goals of the military government, which wanted to normalize fear and obedience and mythologize the sources of its political power." 32

To be sure, performance artists of the Orange Solidarity Alternative, and later broader factions, regularly participated in these Absurd Happenings dressed as mythical, careless Krasnoludki. They jubilantly skipped around burning military vehicles, while others on roller skates distributed free toilet paper, food, and other scarce commodities with childlike abandon and naiveté. Did these seemingly bizarre devices of what Chesters and Welsh call the "tactical frivolity of resistance" 33 demonstrate a loss of sanity throughout sleepless nights on the part of starving, over-worked, exhausted, and involuntarily detoxified artistic social movement members, who were otherwise at a complete loss as to what might provide a breakthrough to end an impenetrable impasse at a crucial juncture of Solidarity's history? Or do these theatrical resistance tactics more accurately represent the spontaneous work of unscripted genius limited to the strict philosophical confines of avant-garde performance machinations offered within the unconventional paradigmatic framework of the Theatre of the Absurd?

\section{DISCUSSION}

I affirm both those perspectives. A cursory glance at events would lead one to conclude that Solidarity's Orange Alternative did indeed represent a haphazard, spontaneous, and messy artistic response to an otherwise critically hopeless situation, by providing an obedient infantile portrayal of state-constructed citizenship that demanded compliant masochistic deference and servitude to the patriarchal authority of Russian oligarchs and their Polish agents. But in retrospect, Orange was more than an assemblage of Solidarity members with a sense of humour.

Orange's conceptualization of the elf was a political satirical embodiment of the ideal type of subjugated citizen serving delegitimated authorities, and it is important to note that the symbol was metaphorically constructed by the most unruly and disobedient anarchistic members of

32. Misztal, "Between the State and Solidarity", p. 65.

33. Chesters and Welsh, Complexity and Social Movements, p. 53. 
the Solidarity movement. Artists subscribing to the school of the Absurd were a particularly marginalized fringe faction of Solidarity who, based on aesthetic and philosophical worldviews, were probably least capable of conforming to the sadistic normative Soviet fantasies to create a race of docile and subservient Poles that so many previous oppressors had unsuccessfully attempted to engineer throughout history. During the most tense and vulnerable periods of opposition, social movement factions did not succumb to communist domination precisely because the Orange fringe of the Solidarity movement provided an unlimited, uncompromising, unwavering, and unpredictable resistance effort of peaceful volatility. As carriers of oppositional consciousness, Solidarity's Orange fringe members had perhaps the most at stake due to the fact that they were the least capable of developing survival strategies or otherwise adapting within the existing atmosphere of demoralizing human repression so prevalent under Soviet tyranny. In a strategy described by Morris and Braine,

The existence of collective identities and injustice frames within oppressed populations does not mean that such groups can be easily mobilized to engage in risky and protracted collective action. Indeed, within oppressed populations certain subcultures of subordination inhibit collective action. These cultures of subordination arise because oppressed populations devise survival strategies that enable them to cope with adverse social conditions they encounter on a regular basis. [These] accounts often overlook the coexistence of oppositional cultures with cultures of subordination. Rather than running along parallel tracks, cultures of subordination and cultures of opposition travel crisscrossing routes with frequent collisions. Carriers of an oppositional consciousness perform several tasks. They highlight and reinterpret countercultural expressions previously somewhat camouflaged. Systems of human domination thus give rise to the conditions that generate oppositional cultures as well as oppositional consciousness. 34

Like all social movements, Solidarity was simultaneously composed of cultures of subordination and of opposition. The Orange Alternative's successful instrumentality in dismantling Soviet aggression was rooted in its deployment of tacit and overt discursive devices that inadvertently fulfilled all three of the requisite dimensions of Hegelian recognition claims for optimizing human potential. First, the deployment of Krasnoludki served as a nostalgic device to remind participants of the important childhood elements that were and should be provided in the sphere of family and intimate partnerships, representing important Polish cultural socialization processes that were under vicious attack by Soviet 
authorities. As is certainly the case with many other cultures, parents and the family are the primary location of human development and emotional security, providing children with a safe space for exploring mythical worlds of illusory delight through nursery rhymes and allegorical characters such as elves, leprechauns, dwarfs, and fairies. ${ }^{35}$

Success by Solidarity's Orange Alternative was also made possible by the strategic use of humour to address citizen relations with the state, by underscoring the inability of Polish people effectively to placate the paternalistic Soviet regime. Performing as the ultimate embodiment of obedience and subservience in the role of the Polish-communist citizenbuffoon, and costumed as the requisite clowning dwarf who voluntarily submits to the dehumanizing degradation rituals needed to endure societal humiliation under totalitarianism, the Orange Alternative offered the masses a prophetic vision of the future, which paradoxically prevented further degradations. By visually triggering a classic metaphoric vision of the court jester and king under absolute monarchy, Solidarity's Orange resistance provided an important cue for Poland's imminent but escapable totalitarian future if movement members were to regress and give in to fear, allowing Solidarity to falter.

By depicting citizen's fate as one of elf-like subservience and docility, and by reminding conventional Solidarity members of the church and state's reluctance to recognize the human autonomy of Polish civilians in any sphere, public or private, the Orange Alternative illustrated that movement failure was not in the realm of possible options because the polity would invariably be reduced to greater slavery and servitude. Thus, the public display of innocent playful Orange Krasnoludki, juxtaposed against the dominant, blood-red destructive military accoutrements of communism, represented an effective dramaturgical device acutely symbolizing the devastating effects that totalitarianism, left unfettered, would continue to have upon the young minds of generations to come.

The unique liberation project offered by the Orange Alternative was that as a social movement it went beyond simple rejection of available options on the negotiating table offered by well-intentioned institutions from the West. Orange was a true social constructivist project that instilled in people the possibility of navigating their own fate. The cognitive limitlessness of an Orange Alternative represented a creative potential intended to inspire Solidarity members to engage not in anarchy, but in avant-garde state design. At a time typified by an absence of progressive thinking under drab, anachronistic Soviet autocracy, Orange disseminated cutting-edge liberation doctrines while simultaneously acknowledging the

35. Kieran Keohane, “Trickster's Metempsychosis in the Mythic Age of Globalization: The Recurrence of the Leprechaun in Irish Political Culture", Cultural Politics, I (2003), pp. 257278. 
importance of certain familiar elements drawn from traditional fraternal ideologies driving Solidarity. Just as Polish identity remains inextricably linked to papal authority and the common good, orange, after all, cannot exist without pigments extracted from yellow or red.

\section{CONCLUSION}

Despite the international social scientific community's neglect of this unique historical faction of activists, humorous theatrical devices disseminated by scripted and unscripted Orange resistance productions provided Solidarity with an arsenal of emotional tactics as part of what Jackman refers to as "petty acts of sabotage that lie behind the grand theatre of compliance". ${ }^{36}$ By dramatizing triviality and other paradigmatic instruments available in the Theatre of the Absurd, the Orange Alternative accomplished several objectives.

First, it helped to dismantle aggression through emotional nostalgic non-verbal symbolic devices. Second, it provided a humorous visual reminder of citizen submission obligations under cultural domination policies articulated by the Soviet regime and many other oppressors before. Third, it simultaneously de-legitimized all three forms of Weberian authority by questioning the rationality and competency of the Soviet Union's legal-rational authority, Wałęsa's charismatic authority, and the Catholic Church's traditional authority all at once. Fourth, by taking matters into their own hands, performance artists demonstrated that the communists had low or no state capacity in dealing with even the least-threatening, lowest-ranking, fringe members of Solidarity on the selfimposed exiled margins of society. Fifth, staged hyper-obedience resistance tactics illustrated the possibility of the state to engage voluntarily in power-sharing with non-state actors, thereby highlighting the constructivist role that the polity played in bringing these likely conditions to fruition. Sixth, by deploying the avant-garde theatrical devices of the Theatre of the Absurd, allegorical performances serving as contestation demonstrations showed the incongruous objectives of the Soviet regime in the light of human rights, as well as the inability of Soviet despotism to provide the most minimal conditions for human recognition at the level of intimate partners, the family, and the state. Finally, by capturing the underlying human emotions inspiring protesters engaging in an unprecedented historical action against the Soviet empire, Solidarity's Orange Alternative dispelled fears and instead focused on the degradation, docility, and servitude that would be necessary for the people to endure another half century of communism. 
In the light of Poland's turbulent past, those accomplishments are not all that surprising. Poles have had a long history of making recognition claims and defying docility identities being thrust upon them from a variety of oppressors. The significance of the Orange Alternative is that it metaphorically clarified important points of the original struggle that were being unintentionally usurped by Solidarity's conventional mainstream intelligentsia outside the artistic community, through their ties to powerful economic, ideological, and imperial transnational interests. While not amenable to survey data or other social scientific quantification, laughter nevertheless played a crucial role in providing participants with the fortitude and resilience necessary to implement the short-term goals of their struggle.

Unfortunately, their efforts for affective kinship and utopian unity would not be influential in long-term transformation. Cross-border cooperation enabled Hungarians, Ukrainians, and now Belarusians successfully adapt the Orange pathway to their own struggles to combat the resilient deleterious legacies of communism. Given the contemporary socioeconomic and political conditions currently experienced in Poland that can be characterized by an absence of progressive liberation theology once prevalent during the struggle, voluntarily self-imposed consumptive conformity and material acquiescence to capitalism among the new petit bourgeoisie, tendencies towards docility and servitude to facilitate further integration into the EU, and an alienated and fragmented citizenry indicative of widening social distances in competition over scarce resources; it appears that Poland could benefit from another elf revolution now more than ever. 